Article

\title{
In Vitro Inhibition of Zika Virus Replication with Amantadine and Rimantadine Hydrochlorides
}

\author{
Jorge L. Arias-Arias ${ }^{1,2, *}$, Francisco Vega-Aguilar ${ }^{3}$, Dihalá Picado-Soto ${ }^{3}$, Eugenia Corrales-Aguilar ${ }^{2,3}(\mathbb{D}$ \\ and Gilbert D. Loría 2,3,4 \\ 1 Sección de Biología Celular y Molecular, Facultad de Microbiología, Universidad de Costa Rica, \\ San José 11501-2060, Costa Rica \\ 2 Centro de Investigación en Enfermedades Tropicales (CIET), Universidad de Costa Rica, \\ San José 11501-2060, Costa Rica; eugenia.corrales@ucr.ac.cr (E.C.-A.); gilbert.loria@ucr.ac.cr (G.D.L.) \\ 3 Sección de Virología, Facultad de Microbiología, Universidad de Costa Rica, San José 11501-2060, Costa Rica; \\ francisco.vega@ucr.ac.cr (F.V.-A.); dpicado@inciensa.sa.cr (D.P.-S.) \\ 4 Centro de Investigación en Hematología y Trastornos Afines (CIHATA), Universidad de Costa Rica, \\ San José 11501-2060, Costa Rica \\ * Correspondence: jorgeluis.arias@ucr.ac.cr
}

check for updates

Citation: Arias-Arias, J.L.; Vega-Aguilar, F.; Picado-Soto, D.; Corrales-Aguilar, E.; Loría, G.D. In Vitro Inhibition of Zika Virus Replication with Amantadine and Rimantadine Hydrochlorides. Microbiol. Res. 2021, 12, 727-738. https: / / doi.org/10.3390/ microbiolres12030052

Academic Editor: Gene S. Tan

Received: 10 August 2021

Accepted: 11 September 2021

Published: 15 September 2021

Publisher's Note: MDPI stays neutral with regard to jurisdictional claims in published maps and institutional affiliations.

Copyright: (c) 2021 by the authors. Licensee MDPI, Basel, Switzerland. This article is an open access article distributed under the terms and conditions of the Creative Commons Attribution (CC BY) license (https:/ / creativecommons.org/licenses/by/ $4.0 /)$.

\begin{abstract}
Zika virus (ZIKV) is a mosquito-borne flavivirus in which human infection became relevant during recent outbreaks in Latin America due to its unrecognized association with fetal neurological disorders. Currently, there are no approved effective antivirals or vaccines for the treatment or prevention of ZIKV infections. Amantadine and rimantadine are approved antivirals used against susceptible influenza A virus infections that have been shown to have antiviral activity against other viruses, such as dengue virus (DENV). Here, we report the in vitro effectiveness of both amantadine and rimantadine hydrochlorides against ZIKV replication, resulting in a dose-dependent reduction in viral titers of a ZIKV clinical isolate and two different ZIKV reference strains. Additionally, we demonstrate similar in vitro antiviral activity of these drugs against DENV-1 and yellow fever virus (YFV), although at higher drug concentrations for the latter. ZIKV replication was inhibited at drug concentrations well below cytotoxic levels of both compounds, as denoted by the high selectivity indexes obtained with the tested strains. Further work is absolutely needed to determine the potential clinical use of these antivirals against ZIKV infections, but our results suggest the existence of a highly conserved mechanism across flavivirus, susceptible to be blocked by modified more specific adamantane compounds.
\end{abstract}

Keywords: Zika; dengue; yellow fever; antivirals; adamantanes; amantadine; rimantadine

\section{Introduction}

Zika virus (ZIKV) is a member of the genus Flavivirus within the Flaviviridae family, first isolated in 1947 from a rhesus macaque in the Zika Forest, Uganda [1]. It is a mosquitoborne arbovirus transmitted to humans by Aedes aegypti and Aedes albopictus [2]. The virion comprises an enveloped spherical particle with a positive single-stranded RNA genome, phylogenetically related to other flaviviruses of medical importance such as dengue (DENV), yellow fever (YFV), West Nile (WNV), and Japanese encephalitis (JEV) [3]. The first ZIKV human infection was reported in Nigeria in 1954 [4], and more than 50 years later, the virus re-emerged, first in Yap Island in 2007 [5], then in French Polynesia in 2013 [6], and later in South and Central America, particularly in Brazil in 2015 [7]. This last outbreak was declared as a public health emergency of international concern by the World Health Organization (WHO) between February and November 2016.

The clinical spectrum produced by ZIKV range from asymptomatic infections in the majority of cases, to a mild influenza-like illness in $20 \%$ of infected people [5]. Severe manifestations such as Guillain-Barré syndrome occurred in 1/6500 to 1/17,000 individuals 
in endemic regions [8], and during pregnancy consequences such as microcephaly in $2.3 \%$ of babies from infected mothers [9], congenital ZIKV syndrome (CZS), and fetal demise, especially when infection occurring during the first trimester of pregnancy, were observed [10]. Therefore, antivirals against ZIKV are necessary to treat and prevent these virus-induced neurological disorders during fetal development and in adulthood. From an epidemiological perspective, drug therapy is also needed to impair the chain of transmission of the virus [11].

Currently, there are no approved vaccines or antivirals to prevent or provide treatment against ZIKV infections. Researchers have been working on either the re-purposing of long-used drugs or the development of novel antivirals, especially those based on the use of antibodies as therapeutics $[12,13]$. To date, tested drugs are directed against viral and cellular targets and include antibiotics, anticancer and anti-inflammatory compounds, antiparasite compounds, nucleosides analogs and nucleoside synthesis inhibitors, and drugs targeting viral enzymes [14]. However, most of the ongoing ZIKV clinical trials are focused on testing vaccine candidates, and none include the evaluation of small molecule-based drug therapies [12].

Amantadine and its structural analog rimantadine are two Food and Drug Administration (FDA)-approved antiviral therapies with known pharmacokinetics and pharmacodynamics, originally developed against influenza A infections and then applied to other respiratory viruses, i.e., Human parainfluenza viruses (HPIVs) and Respiratory syncytial virus (RSV) [15-20]. Consequently, people have been highly exposed to adamantanes for decades, as these drugs are sold without medical prescription in many countries around the world for the treatment of common colds [21]. Adamantanes have also shown antiviral in vitro activity against the severe acute respiratory syndrome coronavirus SARS-CoV$1[22,23]$, and have been suggested as a possible therapeutic option for the treatment of the COVID-19 coronavirus SARS-CoV-2 [24].

Amantadine and rimantadine are suitable antiviral agents due to their high selectivity, their effectiveness at low concentrations, and their low toxicity at cellular and systemic levels with negligible side effects [25]. Adamantanes have also shown antiviral activity against flaviviruses, such as hepatitis C virus (HCV) [26], WNV [27], and DENV [28,29]. Nevertheless, to date, there are no reports on the use of adamantanes to suppress ZIKV infection. Here we present our work that describes the antiviral in vitro activity of both amantadine and rimantadine hydrochlorides against a ZIKV clinical isolate and two different reference strains.

\section{Materials and Methods}

\subsection{Viruses}

The clinical isolate ZIKV CIET-01 (ZIKV/CR/CIET-01/2016) was previously isolated from the sera of a diagnosed patient in Vero cells from Cercopithecus aethiops (ATCC, Manassas, VA, USA) and confirmed as ZIKV by sequencing [30]. ZIKV MR 766 (ZIKV/UG/MR766/ 1947) and ZIKV R103451 (ZIKV/US/R103451/2016) strains were purchased from American Type Culture Collection (ATCC). Vaccine strain YFV 17D (YFV/US/17D/1937) was isolated from the commercial vaccine YF-VAX ${ }^{\circledR}$ (Sanofi Pasteur, Lyon, France). ZIKV and YFV viruses' stocks were produced in Vero cells by inoculating cellular monolayers at a multiplicity of infection (MOI) of 0.1 and incubating for 5 days with Minimum Essential Medium (MEM, Gibco, Gaithersburg, MD, USA) supplemented with $2 \%$ fetal bovine serum (FBS, Gibco) at $37^{\circ} \mathrm{C}$ in an atmosphere of $5 \% \mathrm{CO}_{2}$. Culture supernatants were collected, centrifuged at $3000 \times g$ for $10 \mathrm{~min}$, aliquoted, and stored at $-80^{\circ} \mathrm{C}$. Culture supernatant from uninfected Vero cells was also collected, stored, and used for mock infections. DENV-1 Angola (D1/AO/XX/1988) strain was supplied by the Instituto de Medicina Tropical Pedro Kourí, Havana, Cuba [31]. DENV-1 stock was produced in C6/36 cells from Aedes albopictus (ATCC) by inoculating a cellular monolayer at an MOI of 0.01 and incubating for 3 days with Roswell Park Memorial Institute medium (RPMI-1640, Gibco) supplemented with $2 \%$ FBS at $33{ }^{\circ} \mathrm{C}$ in $5 \% \mathrm{CO}_{2}$. Then, culture supernatant was collected and centrifuged at 
$3000 \times g$ for $10 \mathrm{~min}$. Before storage at $-80{ }^{\circ} \mathrm{C}, 23 \%$ newborn calf serum (NBCS, Gibco) was added [32]. All viruses were titrated by plaque assay in Vero cells, as previously described [33]. Briefly, 10-fold serial dilutions of viruses were added to Vero confluent monolayers. After $2 \mathrm{~h}$ of adsorption, cells were incubated at $37^{\circ} \mathrm{C}$ in $5 \% \mathrm{CO}_{2}$ for 5 days with MEM AutoMod ${ }^{\mathrm{TM}}$ (Sigma, St. Louis, MO, USA) supplemented with $2 \%$ FBS and $1 \%$ carboxymethylcellulose (Sigma). Plaque numbers were counted after staining with crystal violet.

\subsection{Antivirals}

Amantadine and rimantadine hydrochlorides (Sigma) were dissolved in PBS, pH 7.2 (Gibco) by means of incubation in an ultrasonic bath for $30 \mathrm{~min}$ at $37^{\circ} \mathrm{C}$, to obtain $1 \mathrm{mg} / \mathrm{mL}$ stock solutions that were used immediately upon preparation. Working solutions were prepared by 2 -fold serial dilution in MEM $2 \%$ FBS.

\subsection{Antiviral Activity Assay}

Vero cells were seeded on 48-well tissue culture plates (Greiner Bio-One, Monroe, NC, USA) at a density of 60,000 cells per well with MEM $10 \%$ FBS. After $18 \mathrm{~h}$ of incubation at $37^{\circ} \mathrm{C}$ in an atmosphere of $5 \% \mathrm{CO}_{2}$, cells were infected with either ZIKV CIET-01, ZIKV MR 766, ZIKV R103451, YFV 17D, or DENV-1 Angola at an MOI of 0.1 and allowed to adsorb for $2 \mathrm{~h}$ at $37^{\circ} \mathrm{C}$. Then, cells were washed once with PBS and incubated for $96 \mathrm{~h}$ at $37^{\circ} \mathrm{C}$ $5 \% \mathrm{CO}_{2}$ with MEM $2 \%$ FBS containing $0,6.25,12.5,25,50$, and $100 \mu \mathrm{g} / \mathrm{mL}$ of amantadine hydrochloride $(0,33.3,66.6,133.2,266.4$, and $532.8 \mu \mathrm{M}$, respectively) or rimantadine hydrochloride $(0,28.9,57.8,115.6,231.2$, and $462.4 \mu \mathrm{M}$, respectively). Samples of culture supernatants were taken at 48-, 72-, and 96-h post-infection, and virions were quantified by plaque assays in Vero cells, as described above. The $50 \%$ inhibitory concentration $\left(\mathrm{IC}_{50}\right)$ and $90 \%$ inhibitory concentration $\left(\mathrm{IC}_{90}\right)$, defined as the concentrations of antiviral required to reduce virion production by $50 \%$ and $90 \%$, respectively, were calculated using non-linear regression in the software GraphPad Prism 8.0.

\subsection{Cytotoxicity Assay}

Vero cells were seeded on $\mu$ Clear black 96-well plates (Greiner Bio-One) at a density of 15,000 cells per well with MEM- $10 \%$ FBS. After $18 \mathrm{~h}$ of incubation at $37{ }^{\circ} \mathrm{C} 5 \% \mathrm{CO}_{2}$, cells were mock-infected for $2 \mathrm{~h}$ and labeled with $1 \mu \mathrm{g} / \mathrm{mL}$ Hoechst 33342 (Invitrogen, Carlsbad, CA, USA) for $10 \mathrm{~min}$. Then, cells were washed once with PBS and incubated for $48 \mathrm{~h}$ at $37^{\circ} \mathrm{C} 5 \% \mathrm{CO}_{2}$ with MEM $2 \%$ FBS containing $0,6.25,12.5,25,50$, and $100 \mu \mathrm{g} / \mathrm{mL}$ of amantadine or rimantadine hydrochlorides and $500 \mathrm{nM}$ SYTOX green (Invitrogen). After incubation, fluorescence images of cells were acquired at 200X magnification with a Cytation 3 Cell Imaging Multi-Mode Reader (BioTek, Winooski, VT, USA). Image analysis was performed with the software CellProfiler 2.0 (http:/ / www.cellprofiler.org; Broad Institute, Cambridge, MA, USA) to calculate the percentages of cells with condensed chromatin (brighter Hoechst 33342 + nuclei) and dead cells (SYTOX green + nuclei). The 50\% cytotoxic concentration $\left(\mathrm{CC}_{50}\right)$, defined as the concentration of antiviral that induces 50\% cytotoxicity, was calculated using the percentage of dead cells and non-linear regression in the software GraphPad Prism 8.0.

\subsection{Statistics}

Data were expressed as mean \pm standard deviation (SD) of 3 independent experiments. Statistical significance of the differences between mean values was determined by using a one-way ANOVA followed by a Tukey's post hoc test with the software SigmaPlot 14 (Systat Software Inc., Chicago, IL, USA). The level of significance is denoted in figure legends. 


\section{Results}

3.1. Amantadine and Rimantadine Hydrochlorides Have Antiviral Activity against a ZIKV Clinical Isolate at Different Times Post-Infection

To test the antiviral activity of amantadine and rimantadine hydrochlorides against ZIKV, we infected Vero cells monolayers with the clinical isolate ZIKV CIET-01 and incubated them with different doses of both drugs in the range $0-100 \mu \mathrm{g} / \mathrm{mL}$. Then, we titrated by plaque assay at 48-, 72-, and 96-h post-infection. We observed a dose-dependent reduction in ZIKV titers upon incubation with both amantadine and rimantadine hydrochlorides at all tested times post-infection, as depicted in the raw data and in plots shown in Figures 1 and 2, respectively. The antiviral activity of both drugs against ZIKV was evident as soon as $48 \mathrm{~h}$ post-infection. Therefore, we used this time point for subsequent experiments.
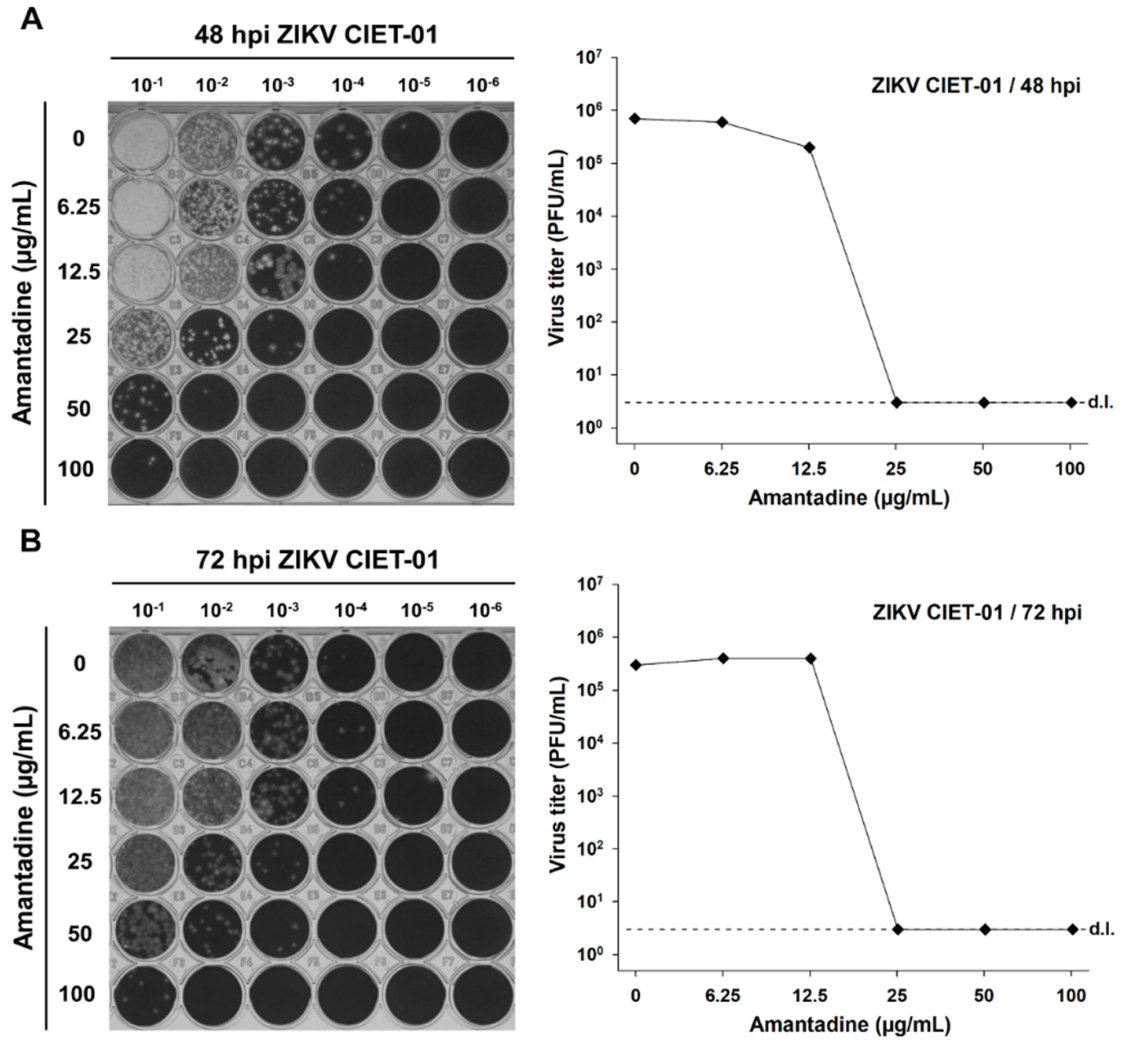

C
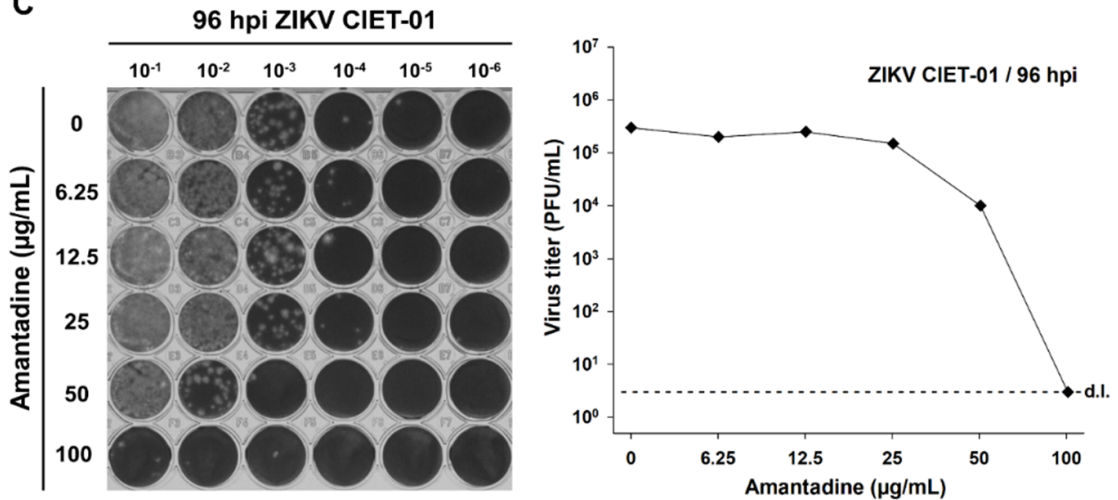

Figure 1. Amantadine hydrochloride suppresses the in vitro replication of a ZIKV clinical isolate. Virion production was quantified by plaque assays of culture supernatants of Vero cells treated with different concentrations of amantadine hydrochloride at 48 (A), 72 (B), and 96 (C) hours post-infection (hpi) with ZIKV clinical isolate CIET-01 at an MOI of 0.1. Data from a single experiment are shown. d.l. = assay detection limit. 

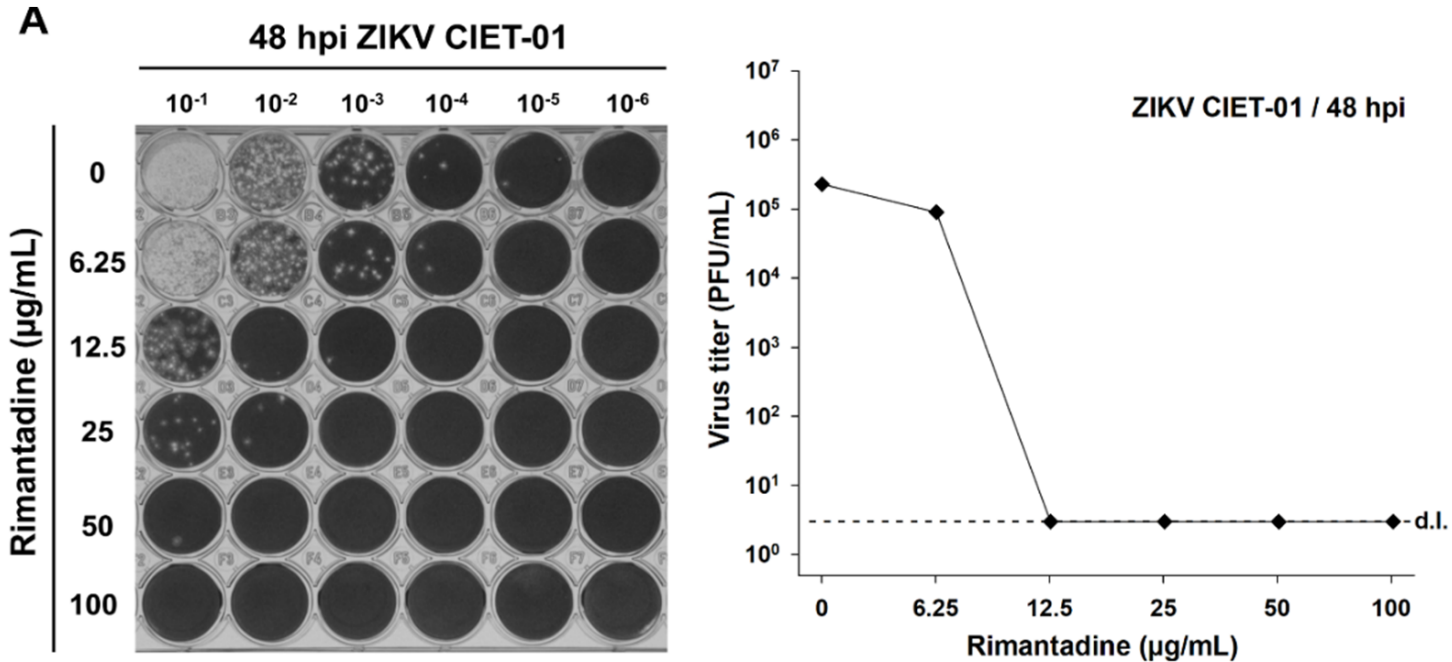

B
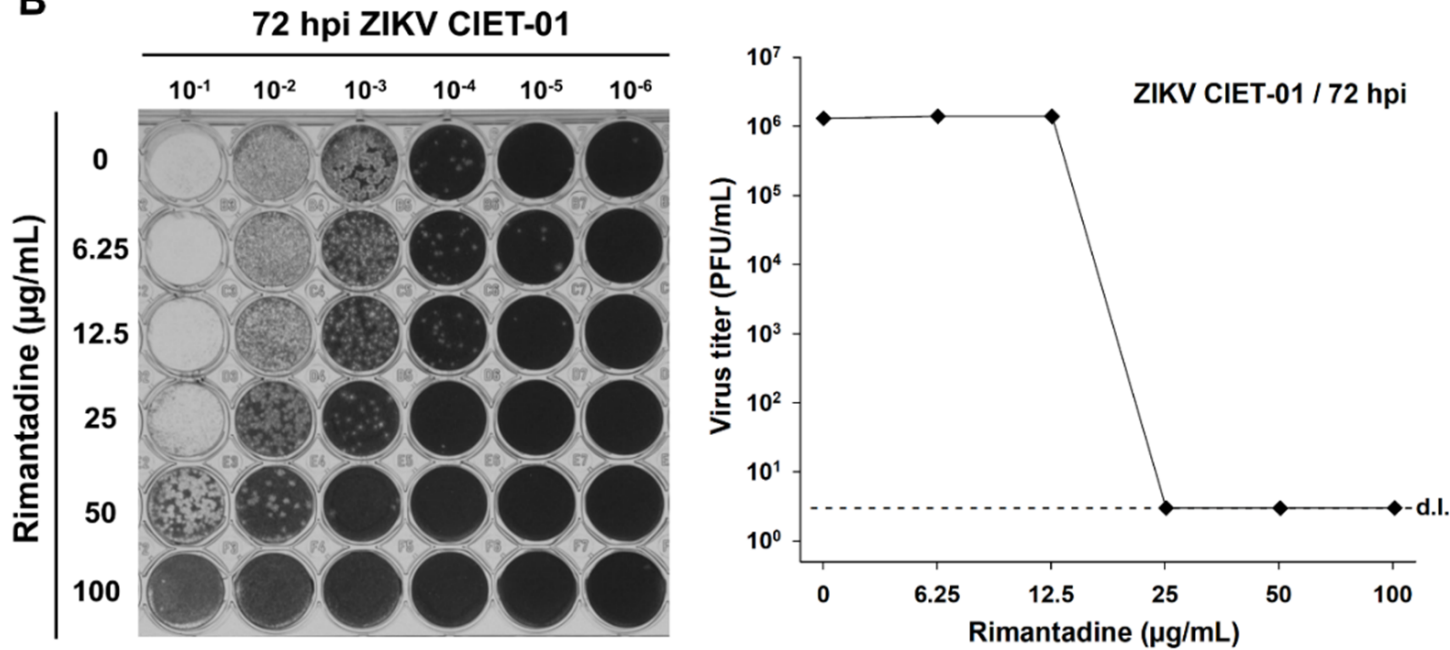

C
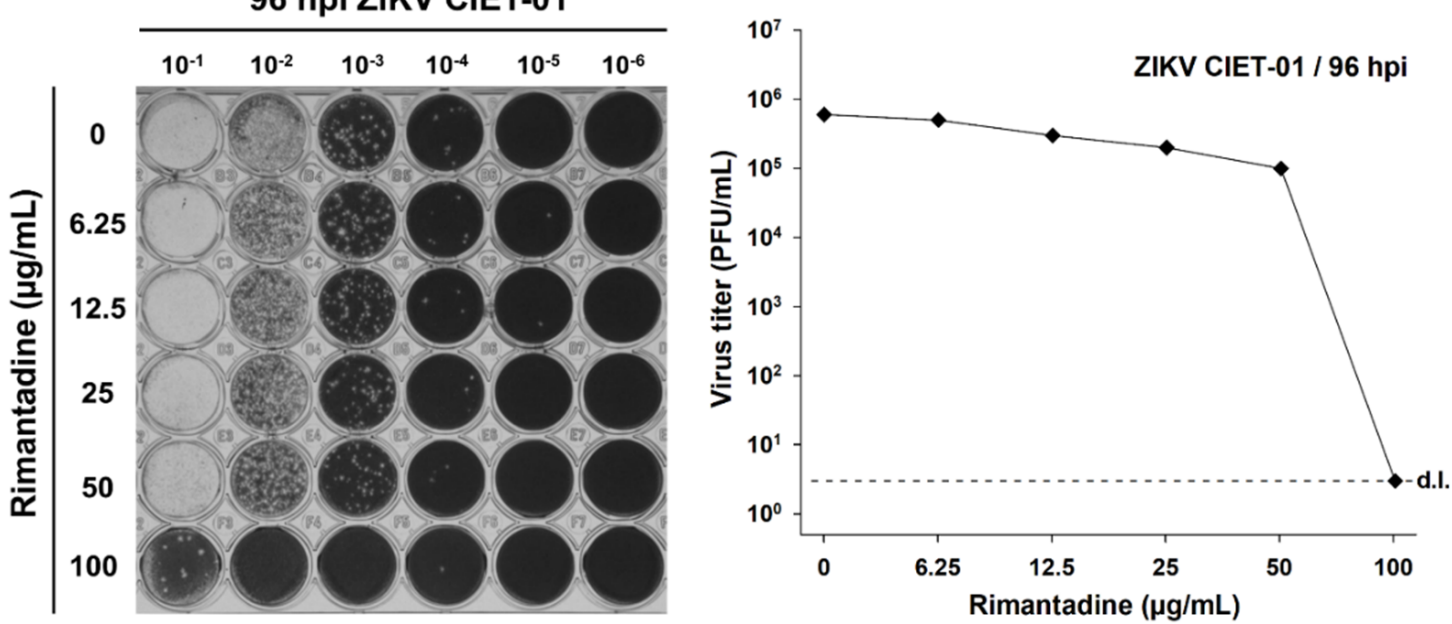

Figure 2. Rimantadine hydrochloride suppresses the in vitro replication of a ZIKV clinical isolate. Virion production was quantified by plaque assays of culture supernatants of Vero cells treated with different concentrations of rimantadine hydrochloride at 48 (A), 72 (B), and 96 (C) hours post-infection (hpi) with ZIKV clinical isolate CIET-01 at an MOI of 0.1. Data from a single experiment are shown. d.l. = assay detection limit. 


\subsection{Antiviral Activity against ZIKV Is Not Explained by a Cytotoxic Effect Induced by the Tested Concentrations of Adamantanes}

To demonstrate that the observed antiviral activity on ZIKV replication was not produced by the cytotoxic side effect of adamantanes on Vero cells, we performed a cytotoxicity assay at $48 \mathrm{~h}$ post-treatment with the previously tested doses $(0-100 \mu \mathrm{g} / \mathrm{mL})$. The percentages of dead cells and cells with condensed chromatin were calculated by SYTOX green and Hoechst 33,342 staining, respectively, as previously described [30]. Even though the percentages of dead cells (cytotoxicity) and cells with condensed chromatin (cell damage) were significantly higher $(p<0.001)$ on cells treated with $100 \mu \mathrm{g} / \mathrm{mL}$ of both amantadine and rimantadine hydrochlorides compared to the untreated cells (Figure 3C, respectively), the calculated $50 \%$ cytotoxic concentrations $\left(\mathrm{CC}_{50}\right)$ were $>100 \mu \mathrm{g} / \mathrm{mL}$ for both drugs. These results demonstrate that the tested doses of adamantanes have no considerable cytotoxic effects on Vero cells and are not responsible for the observed antiviral effect against ZIKV (Figures 1 and 2).
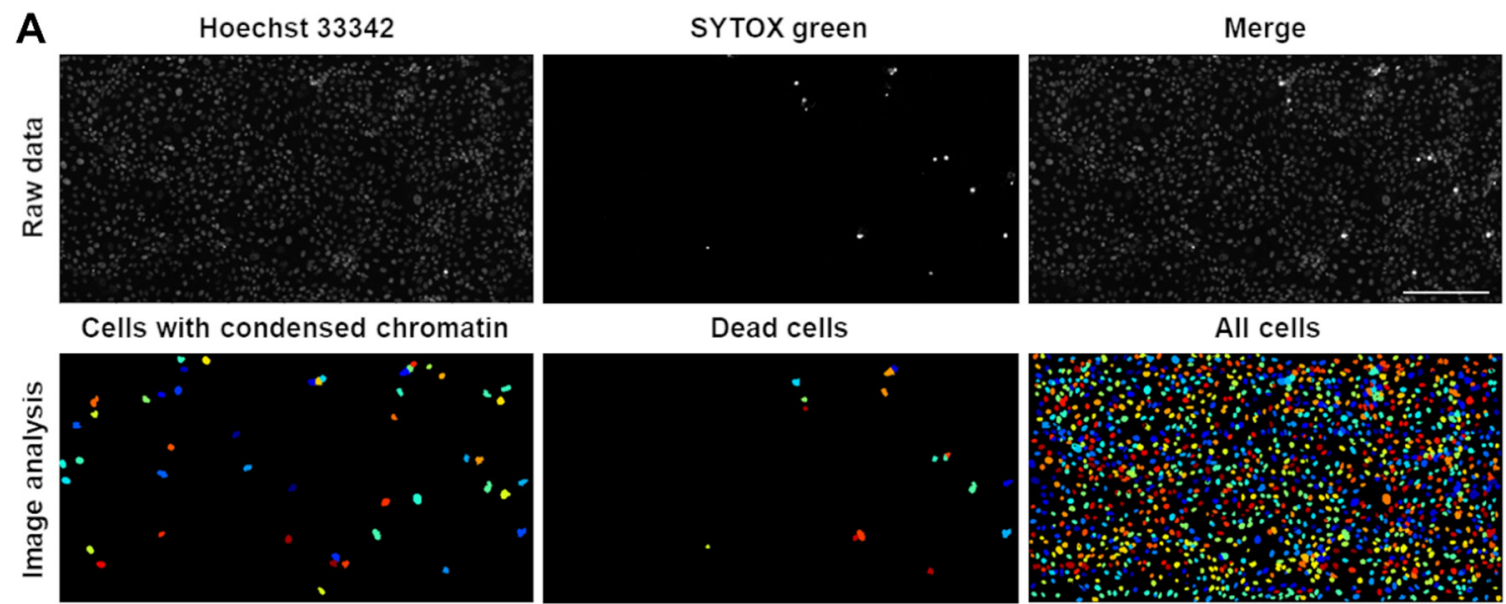

B

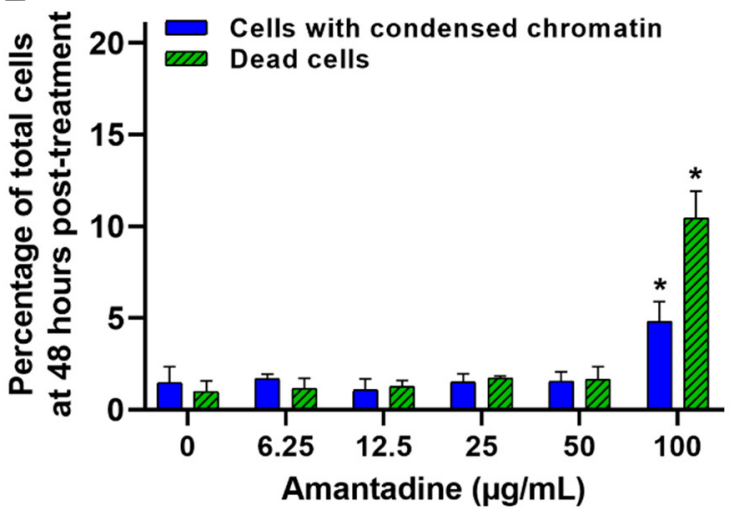

C

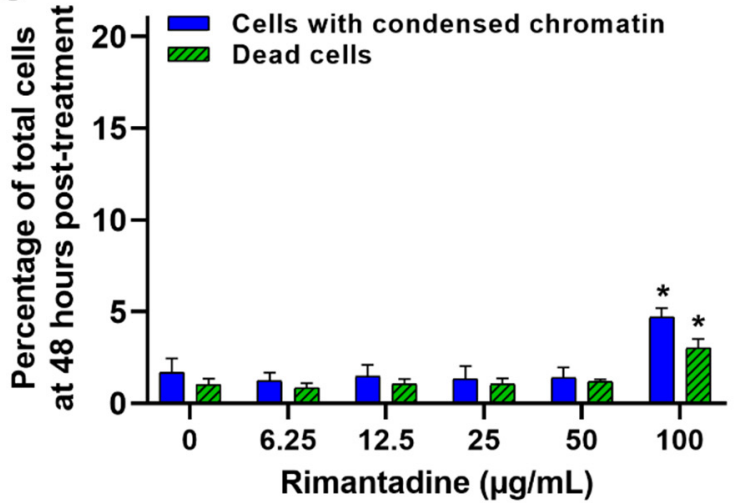

Figure 3. Amantadine and rimantadine hydrochlorides have no significant cytotoxic effect on Vero cells at concentrations with the shown antiviral activity against ZIKV. Vero cells monolayers were Hoechst 33342 stained, and at 48 h posttreatment with culture medium containing a combination of SYTOX green and different concentrations of amantadine or rimantadine hydrochlorides, cells were analyzed by live-cell imaging. (A) Image analysis of Hoechst 33342 and SYTOX green stained Vero cells at $48 \mathrm{~h}$ post-treatment with $50 \mu \mathrm{g} / \mathrm{mL}$ of amantadine hydrochloride, to quantify the number of cells with condensed chromatin and dead cells, respectively. A representative experiment is shown $(n=$ three independent experiments, magnification of 200X, scale bar $=200 \mu \mathrm{m}) .(B, C)$ Percentage of total Vero cells with condensed chromatin and dead cells at $48 \mathrm{~h}$ post-treatment with different concentrations of amantadine or rimantadine hydrochlorides, respectively. $\mathrm{CC}_{50}$ values were $>100 \mu \mathrm{g} / \mathrm{mL}$ for both treatments. Data are expressed as mean $\pm \mathrm{SD}$ of three independent experiments. ${ }^{*} p<0.001$ calculated to cells with the same staining among different antiviral doses. 


\subsection{The Antiviral Activity of Adamantanes Is Also Observed for Other ZIKV Strains and $D E N V-1$, though Only Slightly for YFV}

Finally, we tested the antiviral activity of amantadine and rimantadine hydrochlorides in independent experiments for different ZIKV strains (ZIKV CIET-01, ZIKV MR 766, and ZIKV R103451), DENV-1, and YFV. As defined in previous experiments, we applied doses of both antivirals in the range of $0-100 \mu \mathrm{g} / \mathrm{mL}$, and virion production was quantified at $48 \mathrm{~h}$ post-infection by plaque assays. A dose-dependent reduction in the viral titers was observed for all tested ZIKV strains upon treatment with both adamantanes (Figure 4A-C). The antiviral activity against ZIKVs was also evidenced by the calculated $50 \%$ and $90 \%$ low inhibitory concentrations ( $\mathrm{IC}_{50}$ and $\mathrm{IC}_{90}$, respectively) and high selectivity index (SI) values, as shown in Table 1. Similar results were obtained for DENV-1 (Figure 4D, Table 1), in accordance with previous reports [28,29], but not for YFV (Figure 4E). Among the tested flaviviruses, YFV showed the higher $\mathrm{IC}_{50}$ and $\mathrm{IC}_{90}$ values and the lower SI values (Table 1). These results demonstrated that the observed antiviral activity of adamantanes was reproducible with different ZIKV strains. Compared with other flaviviruses, this activity was similar to that obtained against DENV-1 and superior to the observed for YFV (Table 1).

Table 1. Antiviral activity of amantadine and rimantadine hydrochlorides against ZIKV, DENV, and YFV in vitro ${ }^{\mathrm{a}}$.

\begin{tabular}{|c|c|c|c|c|c|c|}
\hline \multirow{2}{*}{ Virus } & \multicolumn{3}{|c|}{ Amantadine $\left(\mathrm{CC}_{50} \mathrm{~b}>100 \mu \mathrm{g} / \mathrm{mL}\right)$} & \multicolumn{3}{|c|}{ Rimantadine $\left(\mathrm{CC}_{50}>100 \mu \mathrm{g} / \mathrm{mL}\right)$} \\
\hline & $\mathrm{IC}_{50}{ }^{\mathrm{c}}(\mu \mathrm{g} / \mathrm{mL})$ & $\mathrm{IC}_{90} \mathrm{~d}(\mu \mathrm{g} / \mathrm{mL})$ & $\mathrm{SI}^{\mathrm{e}}$ & $\mathrm{IC}_{50}(\mu \mathrm{g} / \mathrm{mL})$ & $\mathrm{IC}_{90}(\mu \mathrm{g} / \mathrm{mL})$ & SI \\
\hline ZIKV CIET-01 & $12.25 \pm 2.28$ & $16.04 \pm 1.94$ & $>8.16$ & $5.89 \pm 0.22$ & $6.96 \pm 0.19$ & $>16.98$ \\
\hline ZIKV MR 766 & $26.52 \pm 12.79$ & $32.62 \pm 9.26$ & $>3.77$ & $8.95 \pm 3.79$ & $36.04 \pm 11.19$ & $>11.17$ \\
\hline ZIKV R103451 & $29.05 \pm 13.79$ & $61.48 \pm 19.00$ & $>3.44$ & $4.91 \pm 2.38$ & $19.60 \pm 4.87$ & $>20.37$ \\
\hline DENV-1 Angola & $12.81 \pm 3.56$ & $35.11 \pm 5.06$ & $>7.81$ & $12.26 \pm 1.67$ & $37.14 \pm 5.54$ & $>8.17$ \\
\hline YFV 17D & $50.62 \pm 8.51$ & $>100$ & $>1.98$ & $74.69 \pm 13.09$ & $>100$ & $>1.34$ \\
\hline
\end{tabular}

Altogether, these results demonstrate that both amantadine and rimantadine hydrochlorides have an antiviral activity against ZIKV that is not explained by a cytotoxic effect on the cellular model, and this antiviral effect is reproducible with different ZIKV strains. 

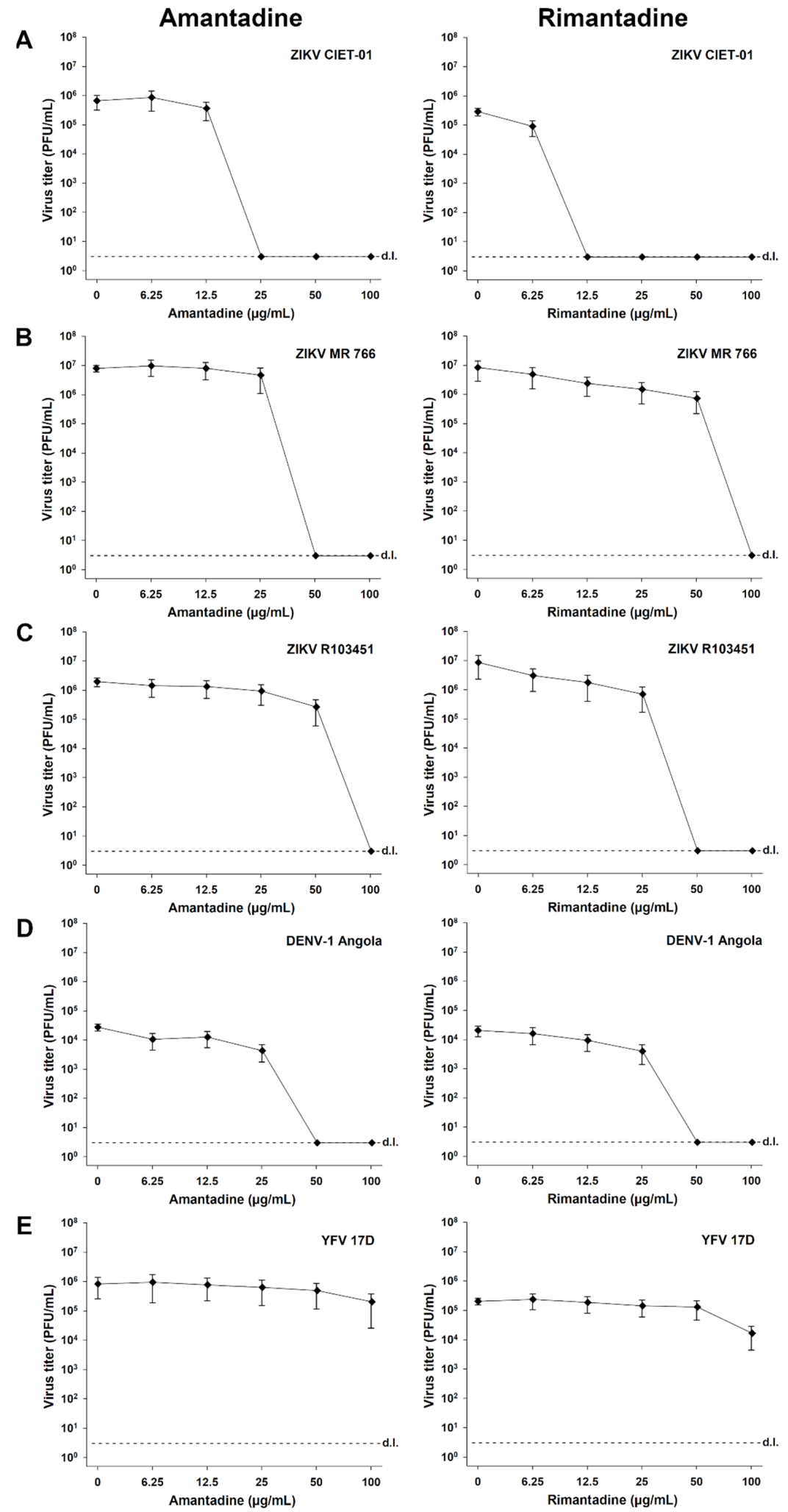

Figure 4. Amantadine and rimantadine hydrochlorides suppress the in vitro replication of different ZIKV strains, DENV-1, and YFV. Virion production was quantified by plaque assays of culture supernatants of Vero cells treated with different concentrations of amantadine or rimantadine hydrochlorides at $48 \mathrm{~h}$ post-infection with ZIKV CIET-01 (A), ZIKV MR 766 (B), ZIKV R103451 (C), DENV-1 Angola (D), and YFV 17D (E) at a MOI of 0.1. Data are expressed as mean \pm SD of three independent experiments. d.l. = assay detection limit. 


\section{Discussion}

Currently, no specific antiviral therapies have been approved for the treatment of ZIKV infections. The search for drugs against ZIKV is being conducted through different approaches, such as the screening of existing compound libraries and the repurposing of validated drugs used in the clinic for the treatment of other diseases, including many already known and used antivirals [34]. In the present work, we show that already approved and widely used antiviral drugs amantadine and rimantadine hydrochlorides inhibit ZIKV replication in vitro, as demonstrated by a dose-dependent reduction in viral titers of a ZIKV clinical isolate and two different reference strains upon incubation with these antivirals (Figure 4). Moreover, the replication of ZIKV was reduced at drug concentrations well below cytotoxic levels with both antivirals, as denoted by the high selectivity indexes obtained with all tested strains (Table 1).

These observations mentioned above are promising and constitute a good starting point aiming to the evaluation of the effectiveness of adamantanes to putatively hinder ZIKV infections in vivo. There is extended evidence about the safety and effectiveness of in vivo use of amantadine and rimantadine hydrochlorides for the prophylaxis and treatment for influenza A infections [35,36]. Amantadine has also shown therapeutic potential in clinical trials for multiple sclerosis [37], depression [38], post-traumatic disorders of consciousness [39], and Parkinson's disease [40], among others conditions. Furthermore, amantadine has been used in vivo as a therapeutic option against other flaviviral diseases, such as hepatitis $C$ and dengue fever, contributing to the clinical improvement of patients in terms of symptoms reduction and shortened recovery time, without notable side-effects at high doses of 200 and $300 \mathrm{mg} /$ day, respectively [41,42].

Taking into account that the majority of ZIKV infections are asymptomatic or produce mild flu-like syndromes, the real target population for a possible antiviral intervention would be high-risk patients and pregnant women. This sets an additional challenge on ZIKV antiviral research as the candidate drugs must be active against the virus but harmless to the mothers and fetuses. Despite theoretical concerns, adamantanes have not been demonstrated to be human teratogens, and there are no causal reports that link their use with any obstetric complications. Pregnancy abnormalities reported in animal studies occur only at very high doses, 16 times higher than the normal dose concentrations used in humans $[43,44]$. Even more, amantadine treatment (200 mg/day) throughout pregnancy has already been reported with favorable fetal outcomes and non-associated complications $[44,45]$. Nevertheless, more studies and careful evaluation are needed on the administration of adamantanes as antiviral therapy in pregnant women.

A hypothetical mechanism for the observed antiviral activity of adamantanes on ZIKV can be proposed by previous findings in the literature. Many clinically important viruses, including HCV and SARS-CoV-1, contain small hydrophobic proteins with ion channel activity, usually less than 100 aminoacids in length with 1 or 2 transmembrane domains (TMDs), collectively known as viroporins [46-50]. By far, the best-characterized member of the viroporin family is the M2 protein, a $\mathrm{H}+$ channel of influenza A virus, which furthermore is the target of amantadine and rimantadine [16,51,52]. Among flaviviruses, amantadine has shown antiviral activity against HCV by a direct action on its P7 viroporin, as demonstrated by the fact that a L20F mutation in the P7 protein confers resistance to this drug in combined therapy with IFN- $\alpha[47,53,54]$. This sets a precedent for the use of adamantanes as antivirals to target flaviviral viroporins. Interestingly, several viroporin candidates were identified in other amantadine-sensitive flaviviruses, such as the $2 \mathrm{~K}$ peptide, the membrane protein $(\mathrm{M})$, and the non-structural proteins NS2A and NS2B of DENV [46,55-57], and the M protein of WNV [46]. Based on these observations and on our data, we hypothesize the presence and dependence of ZIKV replication on a yet unidentified viroporin. The blockage of this putative viroporin could be the mechanism of action of the herein tested adamantanes against ZIKV (Figure 4, Table 1). We found support to this hypothesis in the preliminary work from Brown and collaborators [58]. This research group demonstrated a reduction in the ZIKV envelope protein (E) expression in Vero cells 
upon treatment with the viroporin inhibitor, rimantadine, in a dose dependent manner. Similar to us, this observation made them envisage the potential role of viroporin activity in ZIKV infection. Indeed, they combined molecular dynamic simulations with biochemical approaches to provide evidence that ZIKV M protein functions as a rimantadine-sensitive viroporin within virion membranes, with a potential role during the entry and uncoating of infectious viral particles. They also used in vivo ZIKV preclinical models to demonstrate that rimantadine reduces viraemia, supporting that $M$ protein channel activity is a relevant physiological target to block ZIKV infection [58].

Here we report the in vitro ZIKV susceptibility to both amantadine and rimantadine hydrochlorides. More work is needed to test the effectiveness of these antivirals against ZIKV in vivo, both in animal models and in clinical studies, as this may represent a new approach in the treatment of ZIKV infections by broadening the spectrum of use of these well-validated and already approved antivirals.

Author Contributions: Conceptualization, G.D.L.; methodology, J.L.A.-A.; formal analysis, J.L.A.-A.; investigation, J.L.A.-A., F.V.-A. and D.P.-S.; resources, J.L.A.-A., E.C.-A. and G.D.L.; data curation, J.L.A.-A.; writing—original draft preparation, J.L.A.-A.; writing—review and editing, J.L.A.-A., E.C.A. and G.D.L.; supervision, G.D.L. All authors have read and agreed to the published version of the manuscript.

Funding: This research received no external funding.

Institutional Review Board Statement: Not applicable.

Informed Consent Statement: Not applicable.

Data Availability Statement: Data are contained within the article.

Acknowledgments: The authors thank Claudio Soto-Garita from Instituto Costarricense de Investigación y Enseñanza en Nutrición y Salud, Cartago, Costa Rica, for providing the costarrican clinical isolate ZIKV CIET-01. This work is dedicated with regard to the memory of Lizeth Taylor-Castillo.

Conflicts of Interest: The authors declare no conflict of interest. The funders had no role in the design of the study; in the collection, analyses, or interpretation of data; in the writing of the manuscript, or in the decision to publish the results.

\section{References}

1. Dick, G.W.A.; Kitchen, S.F.; Haddow, A.J. Zika virus. I. Isolations and serological specificity. Trans. R. Soc. Trop. Med. Hyg. 1952, 46, 509-520. [CrossRef]

2. Boyer, S.; Calvez, E.; Chouin-Carneiro, T.; Diallo, D.; Failloux, A.B. An overview of mosquito vectors of Zika virus. Microbes Infect. 2018, 20, 646-660. [CrossRef]

3. Li, Y.; He, L.; He, R.L.; Yau, S.S.T. Zika and flaviviruses phylogeny based on the alignment-free natural vector method. DNA Cell Biol. 2017, 36, 109-116. [CrossRef] [PubMed]

4. Macnamara, F.N. Zika virus: A report on three cases of human infection during an epidemic of jaundice in Nigeria. Trans. R. Soc. Trop. Med. Hyg. 1954, 48, 139-145. [CrossRef]

5. Duffy, M.R.; Chen, T.H.; Hancock, W.T.; Powers, A.M.; Kool, J.L.; Lanciotti, R.S.; Pretrick, M.; Marfel, M.; Holzbauer, S.; Dubray, C.; et al. Zika virus outbreak on Yap Island, Federated States of Micronesia. N. Engl. J. Med. 2009, 360, 2536-2543. [CrossRef] [PubMed]

6. Musso, D.; Bossin, H.; Mallet, H.P.; Besnard, M.; Broult, J.; Baudouin, L.; Levi, J.E.; Sabino, E.C.; Ghawche, F.; Lanteri, M.C.; et al. Zika virus in French Polynesia 2013-14: Anatomy of a completed outbreak. Lancet Infect. Dis. 2018, 18, e172-e182. [CrossRef]

7. Lowe, R.; Barcellos, C.; Brasil, P.; Cruz, O.G.; Honório, N.A.; Kuper, H.; Carvalho, M.S. The zika virus epidemic in brazil: From discovery to future implications. Int. J. Environ. Res. Public Health 2018, 15, 96. [CrossRef] [PubMed]

8. Styczynski, A.R.; Malta, J.M.A.S.; Krow-Lucal, E.R.; Percio, J.; Nóbrega, M.E.; Vargas, A.; Lanzieri, T.M.; Leite, P.L.; Staples, J.E.; Fischer, M.X.; et al. Increased rates of Guillain-Barré syndrome associated with Zika virus outbreak in the Salvador metropolitan area, Brazil. PLoS Negl. Trop. Dis. 2017, 11, e0005869. [CrossRef]

9. Campos Coelho, A.V.; Crovella, S. Microcephaly prevalence in infants born to zika virus-infectedwomen: A systematic review and meta-analysis. Int. J. Mol. Sci. 2017, 18, 1714. [CrossRef]

10. Pierson, T.C.; Diamond, M.S. The emergence of Zika virus and its new clinical syndromes. Nature 2018, 560, 573-581. [CrossRef]

11. Sacramento, C.Q.; De Melo, G.R.; De Freitas, C.S.; Rocha, N.; Hoelz, L.V.B.; Miranda, M.; Fintelman-Rodrigues, N.; Marttorelli, A.; Ferreira, A.C.; Barbosa-Lima, G.; et al. The clinically approved antiviral drug sofosbuvir inhibits Zika virus replication. Sci. Rep. 2017, 7, 40920. [CrossRef] 
12. Gorshkov, K.; Shiryaev, S.A.; Fertel, S.; Lin, Y.W.; Huang, C.T.; Pinto, A.; Farhy, C.; Strongin, A.Y.; Zheng, W.; Terskikh, A.V. Zika virus: Origins, pathological action, and treatment strategies. Front. Microbiol. 2019, 10, 1-17. [CrossRef]

13. Wang, Q.; Yan, J.; Gao, G.F. Monoclonal antibodies against Zika virus: Therapeutics and their implications for vaccine design. J. Virol. 2017, 91, e01049-17. [CrossRef]

14. Saiz, J.C.; Martín-Acebes, M.A. The race to find antivirals for zika virus. Antimicrob. Agents Chemother. 2017, 61, e00411-17. [CrossRef]

15. Bleidner, W.E.; Harmon, J.B.; Hewes, W.E.; Lynes, T.E.; Hermann, E.C. Absorption, distribution and excretion of amantadine hydrochloride. J. Pharmacol. Exp. Ther. 1965, 150, 484-490. [PubMed]

16. Hay, A.J.; Wolstenholme, A.J.; Skehel, J.J.; Smith, M.H. The molecular basis of the specific anti-influenza action of amantadine. EMBO J. 1985, 4, 3021-3024. [CrossRef] [PubMed]

17. Wintermeyer, S.M.; Nahata, M.C. Rimantadine: A clinical perspective. Ann. Pharmacother. 1995, 29, 299-310. [CrossRef] [PubMed]

18. Drakopoulos, A.; Tzitzoglaki, C.; Ma, C.; Freudenberger, K.; Hoffmann, A.; Hu, Y.; Gauglitz, G.; Schmidtke, M.; Wang, J.; Kolocouris, A. Affinity of rimantadine enantiomers against influenza A/M2 protein revisited. ACS Med. Chem. Lett. 2017, 8, 145-150. [CrossRef]

19. Smith, G.B.; Purcell, R.H.; Chanock, R.M. Effect of amantadine hydrochloride on parainfluenza type 1 virus infections in adult volunteers. Am. Rev. Respir. Dis. 1967, 95, 689-690. [CrossRef]

20. Levin, M.J. Treatment and prevention options for respiratory syncytial virus infections. J. Pediatr. 1994, 124, S22-S27. [CrossRef]

21. Kim, M.C.; Lee, N.P. How to treat influenza and colds. West. J. Med. 2000, 172, 260-264. [CrossRef]

22. Chen, F.; Chan, K.H.; Jiang, Y.; Kao, R.Y.T.; Lu, H.T.; Fan, K.W.; Cheng, V.C.C.; Tsui, W.H.W.; Hung, I.F.N.; Lee, T.S.W.; et al. In Vitro susceptibility of 10 clinical isolates of SARS coronavirus to selected antiviral compounds. J. Clin. Virol. 2004, 31, 69-75. [CrossRef]

23. Tanner, J.A.; Zheng, B.J.; Zhou, J.; Watt, R.M.; Jiang, J.Q.; Wong, K.L.; Lin, Y.P.; Lu, L.Y.; He, M.L.; Kung, H.F.; et al. The adamantane-derived bananins are potent inhibitors of the helicase activities and replication of SARS coronavirus. Chem. Biol. 2005, 12, 303-311. [CrossRef] [PubMed]

24. Cimolai, N. Potentially repurposing adamantanes for COVID-19. J. Med. Virol. 2020, 92, 531-532. [CrossRef] [PubMed]

25. Staničová, J.; Miškovský, P.; Šutiak, V. Amantadine: An antiviral and antiparkinsonian agent. Vet. Med. 2001, 46, 244-256. [CrossRef]

26. Martín, J.; Navas, S.; Fernández, M.; Rico, M.; Pardo, M.; Quiroga, J.A.; Zahm, F.; Carreño, V. In vitro effect of amantadine and interferon $\alpha$-2a on hepatitis $C$ virus markers in cultured peripheral blood mononuclear cells from hepatitis $C$ virus-infected patients. Antivir. Res. 1999, 42, 59-70. [CrossRef]

27. Blázquez, A.B.; Martín-Acebes, M.A.; Saiz, J.C. Inhibition of West Nile virus multiplication in cell culture by anti-parkinsonian drugs. Front. Microbiol. 2016, 7, 1-10. [CrossRef] [PubMed]

28. Koff, W.C.; Elm, J.R.; Halstead, S.B. Inhibition of dengue virus replication by amantadine hydrochloride. Antimicrob. Agents Chemother. 1980, 18, 125-129. [CrossRef] [PubMed]

29. Koff, W.C.; Elm, J.R.; Halstead, S.B. Suppression of dengue vitus replication in vitro by rimantadine hydrochloride. Am. J. Trop. Med. Hyg. 1981, 30, 184-189. [CrossRef]

30. Arias-Arias, J.L.; MacPherson, D.J.; Hill, M.E.; Hardy, J.A.; Mora-Rodríguez, R. A fluorescence-activatable reporter of flavivirus NS2B-NS3 protease activity enables live imaging of infection in single cells and viral plaques. J. Biol. Chem. 2020, 295, 2212-2226. [CrossRef] [PubMed]

31. Arias-Arias, J.L.; Vega-Aguilar, F.; Corrales-Aguilar, E.; Hun, L.; Loría, G.D.; Mora-Rodríguez, R. Dengue virus infection of primary human smooth muscle cells. Am. J. Trop. Med. Hyg. 2018, 99, 1451-1457. [CrossRef]

32. Medina, F.; Medina, J.F.; Colon, C.; Vergne, E.; Santiago, G.A.; Munoz-Jordan, J.L. Dengue virus: Isolation, propagation, quantification, and storage. In Current Protocols in Microbiology; Wiley: Hoboken, NJ, USA, 2012; pp. 15D.2.1-15D.2.24, ISBN 9780471729259.

33. Morens, D.M.; Halstead, S.B.; Repik, P.M.; Putvatana, R.; Raybourne, N. Simplified plaque reduction neutralization assay for dengue viruses by semimicro methods in BHK-21 cells: Comparison of the BHK suspension test with standard plaque reduction neutralization. J. Clin. Microbiol. 1985, 22, 250-254. [CrossRef]

34. Baz, M.; Boivin, G. Antiviral agents in development for zika virus infections. Pharmaceuticals 2019, 12, 101. [CrossRef] [PubMed]

35. Wendel, H.A.; Snyder, M.T.; Pell, S. Trial of amantadine in epidemic influenza. Clin. Pharmacol. Ther. 1965, 7, 38-43. [CrossRef]

36. Dolin, R.; Reichman, R.C.; Madore, P.; Maynard, R.; Linton, P.N.; Webber-Jones, R.N. A controlled trial of amantadine and rimantadine in the prophylaxis of influenza A infection. N. Engl. J. Med. 1982, 307, 580-584. [CrossRef] [PubMed]

37. Khazaei, M.; Karevan, A.; Taheri, M.; Ghafouri-Fard, S. Comparison of the effects of amantadine and ondansetron in treatment of fatigue in patients with multiple sclerosis. Clin. Transl. Med. 2019, 8, 20. [CrossRef] [PubMed]

38. Raupp-Barcaro, I.F.; Vital, M.A.; Galduróz, J.C.; Andreatini, R. Potential antidepressant effect of amantadine: A review of preclinical studies and clinical trials. Rev. Bras. Psiquiatr. 2018, 40, 449-458. [CrossRef]

39. Giacino, J.T.; Whyte, J.; Bagiella, E.; Kalmar, K.; Childs, N.; Khademi, A.; Eifert, B.; Long, D.; Katz, D.I.; Cho, S.; et al. Placebocontrolled trial of amantadine for severe traumatic brain injury. N. Engl. J. Med. 2012, 366, 819-826. [CrossRef]

40. Sawada, H.; Oeda, T.; Kuno, S.; Nomoto, M.; Yamamoto, K.; Yamamoto, M.; Hisanaga, K.; Kawamura, T. Amantadine for dyskinesias in parkinson's disease: A randomized controlled trial. PLoS ONE 2010, 5, e15298. [CrossRef] 
41. Maynard, M.; Pradat, P.; Bailly, F.; Rozier, F.; Nemoz, C.; Si Ahmed, S.N.; Adeleine, P.; Trépo, C. Amantadine triple therapy for non-responder hepatitis C patients. Clues for controversies (ANRS HC 03 BITRI). J. Hepatol. 2006, 44, 484-490. [CrossRef]

42. Lin, C.C.; Chen, W.C. Treatment effectiveness of amantadine against dengue virus infection. Am. J. Case Rep. 2016, 17, 921-924. [CrossRef]

43. Vernier, V.G.; Harmon, J.B.; Stump, J.M.; Lynes, T.E.; Marvel, J.P.; Smith, D.H. The toxicologic and pharmacologic properties of amantadine hydrochloride. Toxicol. Appl. Pharmacol. 1969, 15, 642-665. [CrossRef]

44. Levy, M.; Pastuszak, A.; Koren, G. Fetal outcome following intrauterine amantadine exposure. Reprod. Toxicol. 1991, 5, 79-81. [CrossRef]

45. Kirshon, B.; Faro, S.; Zurawin, R.K.; Samo, T.C.; Carpenter, R.J. Favorable outcome after treatment with amantadine and ribavirin in a pregnancy complicated by influenza pneumonia. A case report. J. Reprod. Med. Obstet. Gynecol. 1988, 33, $399-401$.

46. Tomar, P.P.S.; Oren, R.; Krugliak, M.; Arkin, I.T. Potential viroporin candidates from pathogenic viruses using bacteria-based bioassays. Viruses 2019, 11, 632. [CrossRef]

47. Griffin, S.D.C. Plugging the holes in hepatitis C virus antiviral therapy. Proc. Natl. Acad. Sci. USA 2009, 106, 12567-12568. [CrossRef] [PubMed]

48. Torres, J.; Maheswari, U.; Parthasarathy, K.; Ng, L.; Liu, D.X.; Gong, X. Conductance and amantadine binding of a pore formed by a lysine-flanked transmembrane domain of SARS coronavirus envelope protein. Protein Sci. 2007, 16, 2065-2071. [CrossRef]

49. Verdiá-Báguena, C.; Nieto-Torres, J.L.; Alcaraz, A.; DeDiego, M.L.; Torres, J.; Aguilella, V.M.; Enjuanes, L. Coronavirus E protein forms ion channels with functionally and structurally-involved membrane lipids. Virology 2012, 432, 485-494. [CrossRef] [PubMed]

50. Charlton, F.W.; Pearson, H.M.; Hover, S.; Lippiat, J.D.; Fontana, J.; Barr, J.N.; Mankouri, J. Ion Channels as therapeutic targets for viral infections: Further discoveries and future perspectives. Viruses 2020, 12, 844. [CrossRef]

51. Lamb, R.A.; Choppin, P.W. Identification of a second protein (M2) encoded by RNA segment 7 of influenza virus. Virology 1981, 112, 729-737. [CrossRef]

52. Pinto, L.H.; Holsinger, L.J.; Lamb, R.A. Influenza virus M2 protein has ion channel activity. Cell 1992, 69, 517-528. [CrossRef]

53. Mihm, U.; Grigorian, N.; Welsch, C.; Herrmann, E.; Kronenberger, B.; Teuber, G.; Von Wagner, M.; Hofmann, W.P.; Albrecht, M.; Lengauer, T.; et al. Amino acid variations in hepatitis $C$ virus $\mathrm{p} 7$ and sensitivity to antiviral combination therapy with amantadine in chronic hepatitis C. Antivir. Ther. 2006, 11, 507-519. [PubMed]

54. Foster, T.L.; Verow, M.; Wozniak, A.L.; Bentham, M.J.; Thompson, J.; Atkins, E.; Weinman, S.A.; Fishwick, C.; Foster, R.; Harris, M.; et al. Resistance mutations define specific antiviral effects for inhibitors of the hepatitis C virus p7 ion channel. Hepatology 2011, 54, 79-90. [CrossRef] [PubMed]

55. Premkumar, A.; Horan, C.R.; Gage, P.W. Dengue virus M protein C-terminal peptide (DVM-C) forms ion channels. J. Membr. Biol. 2005, 204, 33-38. [CrossRef] [PubMed]

56. Shrivastava, G.; García-Cordero, J.; León-Juárez, M.; Oza, G.; Tapia-Ramírez, J.; Villegas-Sepulveda, N.; Cedillo-Barrón, L. NS2A comprises a putative viroporin of Dengue virus 2. Virulence 2017, 8, 1450-1456. [CrossRef] [PubMed]

57. León-Juárez, M.; Martínez-Castillo, M.; Shrivastava, G.; García-Cordero, J.; Villegas-Sepulveda, N.; Mondragón-Castelán, M.; Mondragón-Flores, R.; Cedillo-Barrón, L. Recombinant Dengue virus protein NS2B alters membrane permeability in different membrane models. Virol. J. 2016, 13, 1-11. [CrossRef]

58. Brown, E.; Lefteri, D.; Singh, R.; Thompson, R.; Maskell, D.; Bentham, M.; Swinscoe, G.; Merits, A.; Donald, C.; Naransonleedsacuk, N.R.; et al. Inhibitors of the small membrane ( M ) protein viroporin prevent Zika virus infection. bioRxiv 2021, 1-49. [CrossRef] 